\title{
Effect of Varied Culture Conditions on Crude Supernatant (Bacteriocin) Production from Four Lactobacillus Species Isolated from Locally Fermented Maize (Ogi)
}

\author{
C.E Onwuakor ${ }^{1, *}$, V.O Nwaugo ${ }^{2}$, C.J Nnadi ${ }^{2}$, J.M Emetole ${ }^{3}$ \\ ${ }^{1}$ Department of Microbiology, College of Natural Sciences, Michael Okpara University of Agriculture Umudike, Abia State, Nigeria \\ ${ }^{2}$ Department of Microbiology, Faculty of Biological \& Physical Sciences, Abia State University Uturu, Abia State, Nigeria \\ ${ }^{3}$ Department of Product Development Programme, National Root Crop Research Institute Umudike, Abia State, Nigeria \\ *Corresponding author: chijiokeonwuakor@gmail.com
}

Received August 24, 2014; Revised August 30, 2014; Accepted September 04, 2014

\begin{abstract}
This Lactic acid bacteria (LAB) predominates the micro flora of fermented products. They produce metabolites that inhibit the growth of food borne pathogens and spoilage microorganisms. The isolation and identification of LAB from fermented maize (Ogi) and the effect of varied culture conditions on crude supernatant production and activity was evaluated. Four (4) isolates of bacteriocin producing lactobacillus species (L. lactis, L. fermentum, L. casei and L. plantarum) with antibacterial activity against Salmonella typhimurium (ATCC 14028) and Shigella dysenteriae (ATCC 23351) were subjected to varying growth medium conditions. The crude supernatant production was tested at different physical and cultural conditions such as temperature (25, 30, 35 and $\left.40^{\circ} \mathrm{C}\right), \mathrm{pH}(5,6,7$ and 8), sodium chloride $(\mathrm{NaCl})$ concentration (2, 4, 6 and 8\%) and incubation duration (12, 24, 48 and 72 hours). The optimum bacteriocin production judged by their different zones of inhibition of crude supernatant was recorded at temperature, $30^{\circ} \mathrm{C}$ and then $35^{\circ} \mathrm{C}$. There were significant differences between all the incubation temperatures at $\mathrm{P}<0.05$. Duration of incubation showed highest crude supernatant activity after 72 hours. Furthermore, optimal conditions for crude supernatant production were observed to be highest at $\mathrm{pH} 6.0$ followed by 5.0 and then $2 \% \mathrm{NaCl}$ concentration. There were significant differences between the zones of inhibition of crude supernatants produced against the indicator organisms at various media $\mathrm{pH}$ and salt concentrations at $\mathrm{P}<0.05$. These crude supernatants may have a potential use in reducing contaminations during industrial processes, as food preservatives and may help in improving the gastro-intestinal tract by fighting off pathogenic bacteria.
\end{abstract}

Keywords: varied, culture, crude supernatant, bacteriocin, production, lactobacillus, fermented, maize, Ogi

Cite This Article: C.E Onwuakor, V.O Nwaugo, C.J Nnadi, and J.M Emetole, "Effect of Varied Culture Conditions on Crude Supernatant (Bacteriocin) Production from Four Lactobacillus Species Isolated from Locally Fermented Maize (Ogi).” American Journal of Microbiological Research, vol. 2, no. 5 (2014): 125-130. doi: 10.12691/ajmr-2-5-1.

\section{Introduction}

Food is any substance or mixture of substances both solid and liquid, which are intended for human consumption or ingestion for their nutritional support for the body or pleasurable benefits. It usually consists of plant or animal origin, which contains essential nutrients such as carbohydrates, fats, proteins, vitamins or minerals and is ingested and assimilated by an organism to produce energy, stimulate growth and maintain life [1,2].

The lactic acid bacteria (LAB) are a group of Gram positive bacteria, non-respiring, non-spore forming, cocci or rods, which produce lactic acid as the major end product of the fermentation of carbohydrates. They are the most important bacteria in desirable food fermentations, being responsible for the fermentation of sour dough bread, sorghum beer, all fermented milk, cassava (to produce garri and fufu) and most "pickled” (fermented) vegetables $[3,4]$. Lactic acid bacteria occur naturally in several raw materials like milk, meat and flour used to produce foods. LAB is used as natural or selected starter cultures in food fermentations in which they perform acidification due to production of lactic acids. Protection of food from spoilage and pathogenic microorganisms by LAB is through producing organic acids [5]. The LAB produces an array of antimicrobial substances (such as organic acids, diacetyl, acetone, hydrogen peroxide, reuterin, anti-fungal peptides and bacteriocins [6]. Bacteriocins are ribosomally synthesized extracellulary released low molecular-mass peptides or proteins (usually 30-60 amino acids) which have a bactericidal or bacteriostatic effect on other bacteria $[7,8]$. The bacteriocins produced by LAB offer several desirable properties that make them suitable for 
food preservation: (i) are generally recognized as safe substances [7], (ii) are not active and nontoxic on eukaryotic cells, (iii) become inactivated by digestive proteases, having little influence on the gut microbiota, (iv) are usually $\mathrm{pH}$ and heat-tolerant, (v) they have a relatively broad antimicrobial spectrum, against many food-borne pathogenic and spoilage bacteria, (vi) they show a bactericidal mode of action, usually acting on the bacterial cytoplasmic membrane: no cross resistance with antibiotics, and (vii) their genetic determinants are usually plasmid-encoded, facilitating genetic manipulation [9].

The inhibitory spectrum of bacteriocins can be narrow and confined to closely related species, or it can be relatively broad, inhibiting a range of target organisms, including food-spoilage and pathogenic bacteria, such as Listeria monocytogenes, Bacillus cereus, Clostridium tyrobutyricum, methicillin-resistant Staphylococcus aureus and vancomycin-resistant enterococci. In general, bacteriocins act mainly by pore formation in target cell membranes, or by inhibiting cell wall synthesis or enzyme activities in the cytosol (RNAse or DNAse) [9].

Ogi (Akamu) is a product of fermented maize (Zea mays) widely eaten in Africa [10,11]. Similar maize preparations in Ghana are referred to as "Akana" or "Kenkey". Ogi is often marketed as a wet cake formerly wrapped in leaves but presently in transparent polythene bags. Gelatinized Ogi (a porridge) called "pap” is mainly used as a breakfast meal for adults and weaning food by low income earners who cannot afford the more expensive imported weaning foods [12]. In most parts of Africa especially in Nigeria, children are fed with mashed adult foods. These foods are bulky and this therefore reduces food intake by a child, often resulting in malnutrition. The development of nutritionally balanced calorie less dense, low bulk and easily digestible weaning food becomes necessary. This involves the use of simple but time consuming traditional technology called fermentation [13]. The traditional fermentation method employed in Ogi production is a wild process and microorganisms are not controlled [14]. Microbiological analyses have shown the presence of several genera of bacteria, moulds and yeasts in the fermented maize product-Ogi $[15,16]$.

In the present study, different culture conditions were adjusted for crude bacteriocin (crude supernatant) production using Lactobacillus isolates from locally fermented maize (Ogi) to determine optimal fermentation conditions for crude supernatant production.

\section{Materials and Methods}

\subsection{Fermented Products}

Ten (10) fermented maize (Ogi) samples bought from Oshodi and Odo markets, Lagos State, Nigeria were analyzed.

\subsection{Test Organisms}

Pure strains of pathogenic gram negative bacteria responsible for food infections; Salmonella typhimurium (ATCC 14028) and Shigella dysenteriae (ATCC 23351) were obtained from the Nigerian Institute of Medical Research laboratory (NIMR) Yaba, Lagos, Nigeria and maintained on agar slants at $4^{\circ} \mathrm{C}$ in the refrigerator.

\subsection{Isolation of Lactic Acid Bacteria from Ogi}

One (1) gram of a 72hrs fermented Ogi was transferred into $5 \mathrm{ml}$ peptone water (Merck, Germany) and serially diluted (10 fold dilutions). Then $1 \mathrm{ml}$ of each of the dilution was aseptically transferred into sterile Petri dishes (Pyrex and Anumbra) and 15ml of de Man Rogosa Sharpe (MRS) medium (Merck, Germany) was added using pour plate technique then incubated at $37^{\circ} \mathrm{C}$ for $48 \mathrm{hrs}$ in an anaerobic flask (Oxoid). After incubation, colonies with different morphologies were randomly selected using a flamed platinum wire loop, streak plated and sub cultured on MRS agar plates to obtain pure colonies. All isolates were examined for Gram reaction, production of catalase and oxidase activity.

\subsection{Identification of LAB Isolates}

Isolates were identified using the following tests: ammonia production from arginine, $\mathrm{CO}_{2}$ production from glucose and growth at different $\mathrm{pH}$ values, growth at different $\mathrm{NaCl}$ concentrations and carbohydrate fermentation. LAB isolates were tested for characteristics of Gram staining, cell morphology, colony morphology, motility, carbon dioxide production from glucose, growth at $10^{\circ} \mathrm{C}$ and $45^{\circ} \mathrm{C}$, growth at $\mathrm{pH}$ of 4.4 and 9.6, growth in $6.5 \%$ and $18 \% \mathrm{NaCl}$, catalase reaction by $3 \%$ hydrogen peroxide and carbohydrate fermentation [17].

\subsection{Characterization of Isolates}

LAB strains were characterized according to methods recommended by several authors $[18,19]$. All strains were initially subjected to Gram staining, catalase test, growth at 10 and $45^{\circ} \mathrm{C}$ in MRS broth, gas production from glucose, arginine hydrolysis [20] and growth in the presence of $2 \%, 3 \%, 4 \%, 6.5 \%$ and $10 \%$ of $\mathrm{NaCl}$. The fermentation of carbohydrates (starch, amygdalin, arabinose, cellobiose, fructose, galactose, glucose, lactose, maltose, mannitol, mannose, melizitose, melibiose, raffinose, rhamnose, ribose, sucrose, salicin, sorbitol, trehalose and xylose) was performed in MRS broth (prepared without sugars) containing $1 \%$ solution of carbohydrate and added to $0.025 \%$ bromocresol purple as $\mathrm{pH}$ indicator. Results were recorded after $48 \mathrm{~h}$ of incubation at $30^{\circ} \mathrm{C}$.

\subsection{Detection of Inhibitory Activity of Crude Bacteriocin from Selected Isolates}

Selected LAB isolates were grown in MRS broth at $37^{\circ} \mathrm{C}$ for 24 hrs. Cell free crude supernatant of each isolate was obtained by centrifugation at 3,000xg for $20 \mathrm{~min}$. The supernatant was adjusted to $\mathrm{pH} 6.5$ with $1 \mathrm{M} \mathrm{NaOH}$ and subsequently filter sterilized through a $0.2 \mu \mathrm{m}$ membrane filter (Whatman, Germany). Inhibitory activity was determined using agar well diffusion assay [21]. Inhibitory effect of the hydrogen peroxide in the crude supernatant was eliminated by reacting with $5 \mathrm{mg} / \mathrm{ml}$ catalase added. Suitable agar medium containing $1 \%$ agar $\left(45^{\circ} \mathrm{C}\right)$ was inoculated with each of the two indicator strains. Agar wells of $5 \mathrm{~mm}$ diameter were cut and the filter-sterilized crude supernatant $(20 \mu \mathrm{l})$ was added into each well. The plates were incubated at $37^{\circ} \mathrm{C}$ for $24 \mathrm{hrs}$. The inhibition zones around the wells were measured. 


\subsection{Effect of Varying Culture Conditions on Crude Supernatant Activity}

The selected lactic acid strains were subjected to different culture conditions to derive optimum conditions for crude supernatant production. To study the effect of varying culture conditions, growth and crude supernatant production and thus bacteriocin activity was estimated at varied temperatures $\left(25,30,35\right.$, and $\left.40^{\circ} \mathrm{C}\right) \mathrm{pH}(5.0,6.0$, 7.0 and 8.0$)$, sodium chloride $(\mathrm{NaCl})$ concentrations $(2.0$, 4.0, 6.0 and $8.0 \% \mathrm{w} / \mathrm{v}$ ) and duration of incubation (12, 24, 48, and 72hrs) in MRS broth. All samples were collected after 48hrs, except for those measuring incubation time effects before inhibitory activity was determined by agar well diffusion assay as described above.

\subsection{Data presentation and statistical analysis}

Data were represented as means \pm standard error of mean as well as bar charts. Two-way analysis of variance and Bonferroni's multiple comparison tests using GraphPad Prism (Version 6.0) software were used to analyze data. Values were considered significant when $\mathrm{P}<0.05$.

\section{Results}

\subsection{Isolation of Lactic Acid Bacteria}

In this study, Lactobacillus strains producing antimicrobial compounds were isolated from fermented maize (Ogi). Four (4) Lactobacillus species met basic characteristics of Lactobacilli, and showed antibacterial activity against both indicator organisms. They include $L$. lactis, L. fermentum, L. casei and L. plantarum.

\subsection{Identification of Isolates}

The general properties of $7 \mathrm{LAB}$ strains isolated from Ogi were determined by phenotypic characterization. There production of gas from glucose, hydrolysis of aesculin, arginine and citrate hydrolysis, growth at different temperatures and at different levels of salt were also put into consideration, species were arranged in groups by the carbohydrates fermentation profile (Table 1 and Table 2).

\subsection{Optimization of Culture Conditions}

The broth medium containing each isolate was incubated at various temperatures; 25.0, 30.0, 35.0 and $40.0^{\circ} \mathrm{C}$ and the bacteriocin harvested were tested against Salmonella typhimurium and Shigella dysenteriae (Figure 1 and Figure 2 respectively).

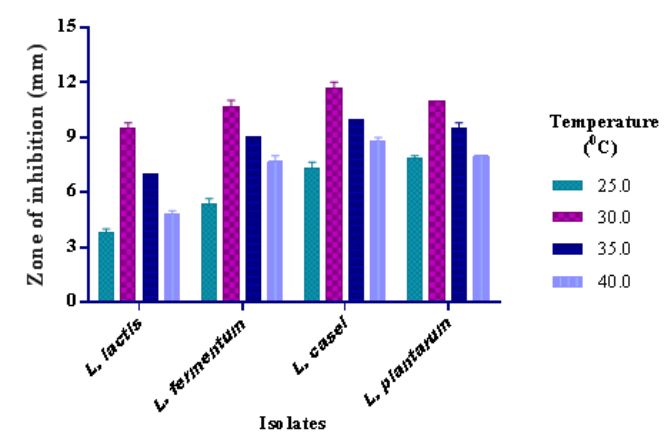

Figure 1. Zone of inhibition (mm) of crude supernatant from different Lactobacillus isolates cultured at varied temperatures $\left({ }^{\circ} \mathrm{C}\right)$ against Salmonella typhimurium

Table 1. Physiological characteristics of lactic acid bacteria strains isolated from Ogi

\begin{tabular}{|c|c|c|c|c|c|c|c|c|c|c|c|c|c|c|c|c|c|c|c|c|}
\hline \multirow{2}{*}{ 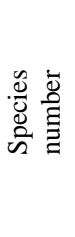 } & \multirow{2}{*}{ 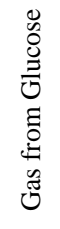 } & \multirow{2}{*}{ 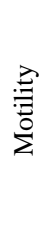 } & \multicolumn{3}{|c|}{ Hydrolysis of } & \multicolumn{5}{|c|}{$\begin{array}{l}\text { Growth at different } \\
\text { temperatures }\left({ }^{0} \mathrm{C}\right)\end{array}$} & \multicolumn{2}{|c|}{$\begin{array}{l}\text { Production } \\
\text { of }\end{array}$} & \multicolumn{3}{|c|}{$\begin{array}{l}\text { Growth at } \\
\text { different pH }\end{array}$} & \multicolumn{5}{|c|}{$\begin{array}{c}\text { Growth in the presence of } \\
\qquad \mathrm{NaCl}(\%)\end{array}$} \\
\hline & & & 焉 & 䒼 & 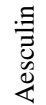 & 10 & 15 & 40 & 45 & 50 & $\frac{\Xi}{0}$ & 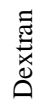 & 6.5 & 9.2 & 9.6 & 2 & 3 & 4 & 6.5 & 10 \\
\hline
\end{tabular}

\begin{tabular}{|c|c|c|c|c|c|c|c|c|c|c|c|c|c|c|c|c|c|c|c|c|}
\hline 1 & - & - & + & - & + & - & - & + & - & - & $\mathrm{V}$ & - & + & + & - & + & + & + & + & - \\
\hline 2 & + & - & + & - & $\mathrm{V}$ & - & + & + & - & - & - & - & + & $\mathrm{v}$ & $\mathrm{V}$ & + & + & + & + & - \\
\hline 3 & + & - & - & - & + & - & + & + & $\mathrm{V}$ & - & - & - & + & - & - & + & + & + & + & - \\
\hline 4 & + & - & - & - & + & - & + & + & - & - & - & - & + & - & - & + & + & + & + & - \\
\hline
\end{tabular}

+: Positive reaction; -: Negative reaction; v: variable. 1. Lactobacillus lactis; 2. Lactobacillus fermentum; 3. Lactobacillus casei; 4. Lactobacillus plantarum

Table 2. Carbohydrate fermentation of lactic acid bacteria strains isolated from

\begin{tabular}{|c|c|c|c|c|c|c|c|c|c|c|c|c|c|c|c|c|c|c|c|c|c|}
\hline 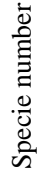 & $\begin{array}{l}\text { U } \\
\text { च } \\
\text { के }\end{array}$ & 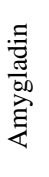 & 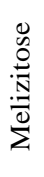 & $\begin{array}{l}\overrightarrow{0} \\
: \frac{0}{7} \\
\stackrel{0}{0} \\
\text { के }\end{array}$ & 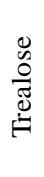 & 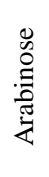 & $\begin{array}{l}\mathscr{W} \\
\stackrel{\Xi}{E} \\
\stackrel{\Xi}{\Xi}\end{array}$ & $\frac{\ddot{D}}{\tilde{\partial}}$ & $\begin{array}{l}\ddot{n} \\
\ddot{\partial} \\
\ddot{\vec{x}}\end{array}$ & 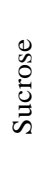 & 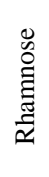 & 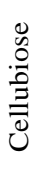 & $\begin{array}{l}\tilde{y} \\
.0 \\
\stackrel{0}{0} \\
\stackrel{0}{g}\end{array}$ & 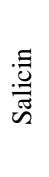 & $\begin{array}{l}\text { 을 } \\
\text { 蒠 }\end{array}$ & 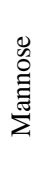 & 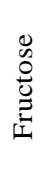 & $\begin{array}{l}\tilde{n} \\
\stackrel{0}{0} \\
\stackrel{0}{\pi} \\
0\end{array}$ & 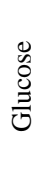 & 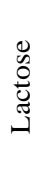 & 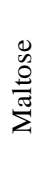 \\
\hline 1 & + & - & - & - & $\mathrm{V}$ & - & - & $\mathrm{V}$ & + & - & - & + & - & + & - & - & + & + & + & + & + \\
\hline 2 & - & - & $\mathrm{V}$ & - & - & + & $\mathrm{V}$ & - & + & $\mathrm{V}$ & - & - & - & - & + & - & + & $\mathrm{V}$ & + & $\mathrm{V}$ & + \\
\hline 3 & - & + & $\mathrm{V}$ & - & + & - & - & - & - & - & - & + & + & + & + & + & + & + & + & - & $\mathrm{V}$ \\
\hline 4 & - & + & + & + & + & - & - & - & + & + & - & + & - & + & + & + & + & + & + & + & + \\
\hline
\end{tabular}




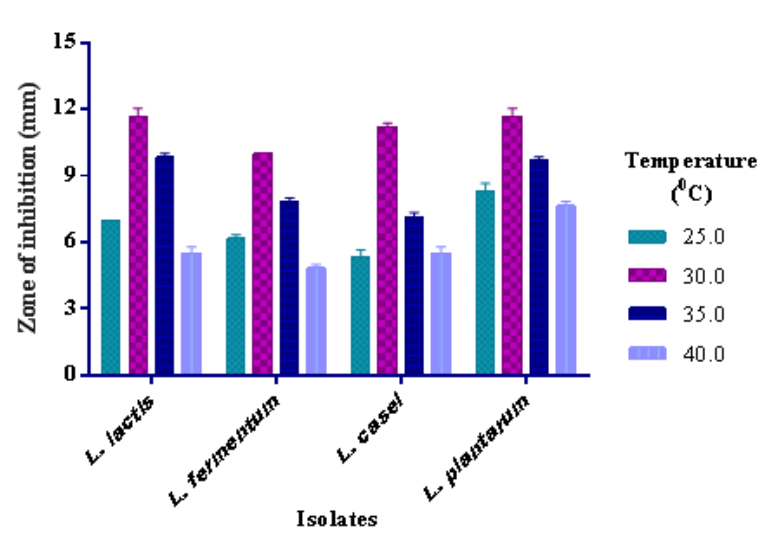

Figure 2. Zone of inhibition (mm) of crude supernatant from different Lactobacillus isolates cultured at varied temperatures $\left({ }^{\circ} \mathrm{C}\right)$ against Shigella dysenteriae

The effect of varied incubating duration (Hrs) on bacteriocin production was noted as different zones of inhibition were observed among the various isolates against the indicator organisms (Figure 3 and Figure 4).

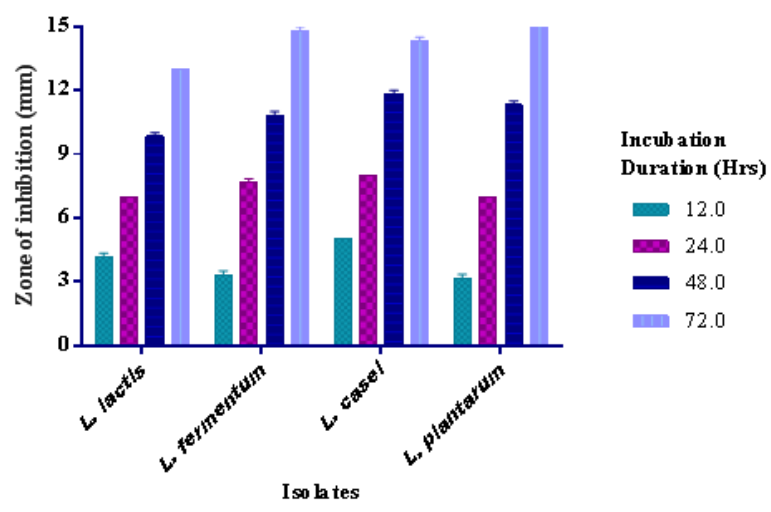

Figure 3. Zone of inhibition (mm) of crude supernatant from different Lactobacillus isolates cultured at varied incubation durations (Hrs) against Salmonella typhimurium

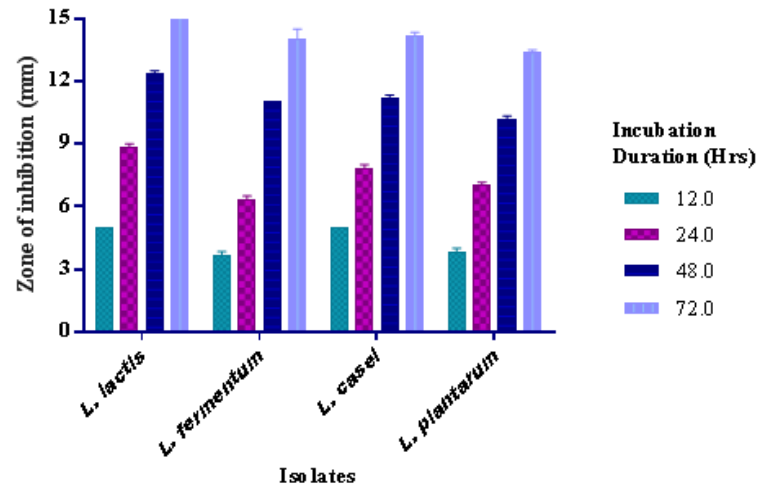

Figure 4. Zone of inhibition (mm) of crude supernatant from different Lactobacillus isolates cultured at varied incubation durations (Hrs) against Shigella dysenteriae

The effect of varied medium $\mathrm{pH}$ and Sodium chloride concentration on bacteriocin production was affected as different zones of inhibition were observed among the various isolates against the indicator organisms (Figure 5 and Figure 6; Figure 7 and Figure 8) respectively

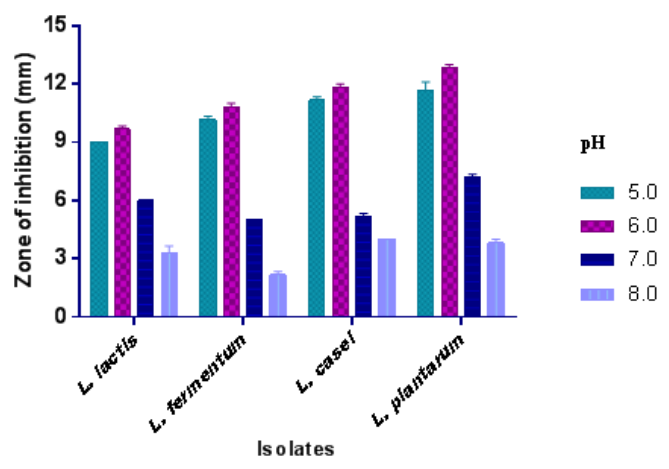

Figure 5. Zone of inhibition (mm) of crude supernatant from different Lactobacillus isolates cultured at varied media $\mathrm{pH}$ against Salmonella typhimurium

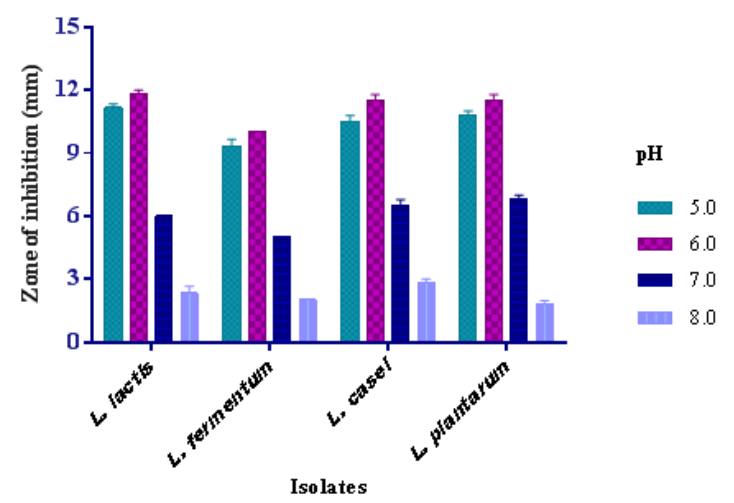

Figure 6. Zone of inhibition (mm) of crude supernatant from different Lactobacillus isolates cultured at varied media $\mathrm{pH}$ against Shigella dysenteriae

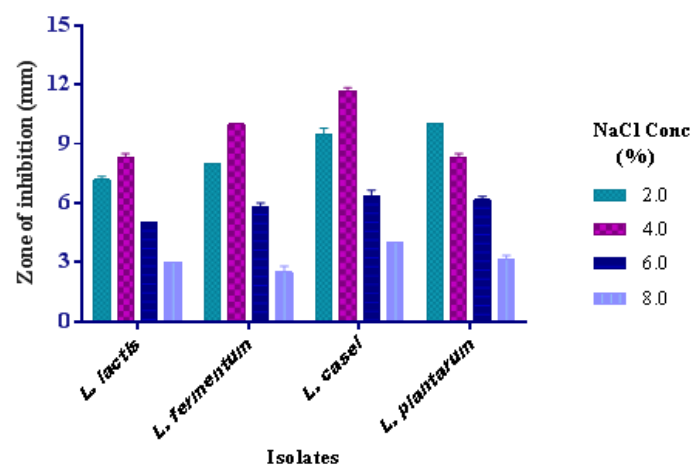

Figure 7. Zone of inhibition (mm) of crude supernatant from different Lactobacillus isolates cultured at varied media sodium chloride concentration against Salmonella typhimurium.

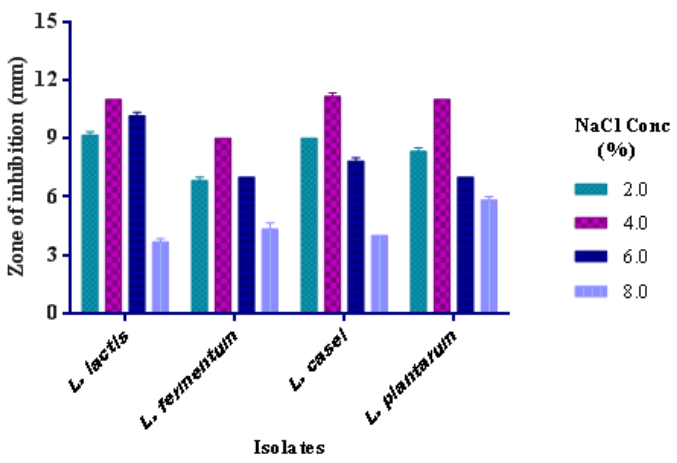

Figure 8. Zone of inhibition (mm) of crude supernatant from different Lactobacillus isolates cultured at varied media sodium chloride concentration against Shigella dysenteriae 


\section{Discussion}

These identified Lactobacillus species were in agreement with those earlier identified from similar fermented food products by [22]. The isolates were then tested for antibacterial activity against the indicator organisms (Salmonella typhimurium and Shigella dysenteriae). The crude supernatant activity from the isolates that showed antibacterial activities were further tested after the culture conditions were varied to determine the effect of different cultural conditions on the antibacterial action of the crude extract produced. Parameters such as incubation duration and temperature, media $\mathrm{pH}$ and salt concentrations were varied.

The effect of varied incubating temperatures on crude supernatant production by the isolates in de Man Rogosa Sharpe broth was determined by its antibacterial activity against the indicator strains. The result showed that antibacterial activity was highest at $30.0^{\circ} \mathrm{C}$ followed by $35.0^{\circ} \mathrm{C}$ as seen in Figure 1 and Figure 2. There were significant differences between the different zones of inhibition produced for all the incubating temperatures (at $\mathrm{P}<0.05$ ). This was in agreement with the work of [23] and [24], which showed that bacteriocin production was affected by different incubating temperatures. The maximum crude supernatant activity recorded at $30^{\circ} \mathrm{C}$ suggests that ambient growth temperature is most ideal for their production by Lactobacillus species.

The effect of varied incubating duration (Hrs) on crude supernatant production was affected as different zones of inhibition were observed among the various isolates against the indicator organisms (Table 3 and Table 4). Optimum crude supernatant production was observed after 72 hours judged by the zones of inhibition against the indicators. There were observable reduction crude supernatant activities as incubation time dropped. There were significant differences between the various incubation times (at $\mathrm{P}<0.05$ ). This result was in complete agreement with [25], which showed that incubation time affects bacteriocin production.

The results obtained in this study regarding crude supernatant activity from media incubated at varied $\mathrm{pH}$ values (Figure 5 and Figure 6) showed optimum activity at $\mathrm{pH} 6$ followed closely by $\mathrm{pH} 5$ for both indicator organisms. There were clear significant differences between $\mathrm{pH} 7$ and 8 but not in pH 5 and 6 as both showed similar zones of inhibition for all the isolates against indicator organisms. This result was consistent with the reports of [26], which showed influence of $\mathrm{pH}$ on growth of vaginal Lactobacilli. This $\mathrm{pH}$ tolerance is an extremely important feature since the isolates have the ability to survive, grow and produce bacteriocins under acidic and alkaline conditions.

Every microorganism has a minimal, a maximal and an optimal $\mathrm{pH}$ for growth and metabolism. Microbial cells are significantly affected by the $\mathrm{pH}$ of their immediate environment because they apparently have no mechanism for adjusting their internal $\mathrm{pH}$.

Furthermore, the effect of varied medium percentage sodium chloride $(\mathrm{NaCl})$ concentration on crude supernatant production and activity was also evaluated. Highest zones of inhibition and consequent optimum crude supernatant production was observed at $\mathrm{NaCl}$ concentration of $4 \%$, but started reducing as salt concentration increased further
(Figure 7 and Figure 8). There was significant difference between zones of inhibition obtained at all the salt concentrations. This was in agreement with [25] who studied cultural parameter for bacteriocin production.

Besides the strong acid medium in the stomach, the probiotic microorganisms taken orally have to defend against the bile salt in the gastrointestinal tract [27]. Hence, bile tolerance is considered to be one of the important properties required for high survival and as a consequence of probiotic activity. The decrease in crude supernatant production as salt concentration increased could be attributed to stress on the isolates.

Microbial food safety is an increasing public health concern worldwide [28,29] and many gram negative bacteria like Escherichia coli, Salmonella serovars, Campylobacter species, Shigella species etc, have been implicated in food borne diseases [25]. Alternate methods for controlling pathogenic bacteria by the production of antimicrobial peptides called bacteriocins are now highly considered. Bacteriocins from lactic acid bacteria have attracted much attention and have been the subject of intensive investigation due to their ability to act as a biopreservative agent, which led to their incorporation into foods, particularly in the dairy foods and also in human therapeutics [30,31,32,33].

\section{Conclusion}

This study thus suggests the use of Lactobacillus species isolated from Ogi in bacteriocin production. Crude supernatants from lactobacillus species harnessed under different culture conditions have shown different antimicrobial potencies. These findings could be applied in the food and pharmaceutical industries to further enhance maximum bacteriocin production at optimal levels to replace conventional antibiotics in combating pathogens that are vastly acquiring antimicrobial resistance. Further work can be done to ascertain the antibacterial effect of the purified forms of the crude supernatants from Lactobacillus species from Ogi to obtain pre bacteriocins and ways in which they could be used in industrial processes to arrest contamination during industrial processes and in local fermented food preservation.

\section{Acknowledgement}

We wish to acknowledge and appreciate all staff of the Microbiology section at the Drug and Vaccine Control Laboratory of the National Agency for Food and Drug administration and Control (NAFDAC), Yaba, Lagos State, Nigeria.

\section{References}

[1] Abdulmumeen, H.A., Risikat, A.N and Sururah, A.R. Food: Its preservatives, additives and applications. International Journal of Chemical and Biological Sciences, 2012, 1: 36-47.

[2] Francis, F.J. Pioneer in Food Sciences and Quality, In: A Century of Food Science. Institute of Food Technologists. 2000.

[3] Savadogo, A., Quattara, C.A.T., Bassole, I.H.N and Traore, S.A. Bacteriocin and lactic acid bacteria, a mini review. African Journal of Biotechnology. 2006, 5 (9): 678-683. 
[4] De Vuyst, L and Leroy, F. Bacteriocins from lactic acid bacteria: production, Purification and food Applications. Journal of Molecular Microbiology and Biotechnology. 2007, 13: 194-199.

[5] Ross, R.P., Morgan S and Hill, C. Preservation and fermentation: Past, present and future. International Journal of Food Microbiology. 2002, 79: 3-6.

[6] El-Ziney, M.G., Debevere, J and Jakobsen, M. Reuterin, In: Naidu, A.S (Ed.), Natural Food Antimicrobial Systems. CRC Press, London. 2000, 567-587.

[7] Galvez, A., Abriouel, H., Lopez, R.L and Omar, N.B. Bacteriocin based strategies for food bio-preservation. International Journal of Food Microbiology. 2007, 120: 51-70.

[8] Klaenhammer, T.R. Genetics of bacteriocins produced by lactic acid bacteria, FEMS Microbiology Reviews. 1993, 12: 39-85.

[9] Tagg, A. S. Dajani, A.S and Wannamaker, L.W. Bacteriocins of Gram positive bacteria. Bacteriological Reviews. 1976, 40: 722756.

[10] Adams, M.R and Moss, M.O. Food Microbiology. 3rd ed. Athenaeum Gateshead, Tyne and Wear, London. 1995, 227-239.

[11] Amakoromo, E.R. Indigenous Fermented Foods of Nigeria: Processing, composition and Improvement. University of Port Harcourt Press, PH, Nigeria. 2011, 57-65

[12] Ozoh, P.T.E and Kuyanbana, Z.U. Microbial quality of pap prepared from cereals sold in Bauchi markets, Nigeria. Int. J. Environ. Health, Res. 1995, 5: 133-141.

[13] Marero, L.M, Pagumo, E.M., Aguinaldo, A.R and Homma, S. Nutritional characteristics of weaning foods prepared from germinated cereals and legumes. J. Food Sci. 1989, 53(8): 13991402.

[14] Mbakwem- Aniebo, C and Udemgba, G. Microbiological quality of untreated and salt-treated Ogi (Akamu) kept at room temperature. Nature and Science. 2012, 10(8): 26-29.

[15] Akinrele, I.A. Fermentation studies on maize during the preparation of a traditional African Starch-cake food. J. Sci. Food Agric. 1970, 21: 619-625.

[16] Odunfa, S.A. African fermented foods. In: Microbiology of Fermented Foods. (Wood, B.J. (Ed.)). Elsevier Applied Science Publishers, New York. 1985, 25-42.

[17] Axelsson, L. Lactic acid bacteria: classification and physiology. In Advance in Lactic Acid Bacteria: Microbiological and Functional Aspects, Salminen, S., Von Wright, A and Ouweland A Editors. Marcel Dekker, New York, U.S.A. 2004, 1-66.

[18] Charteris, W.P., Kelly, P.M., Morelli, L and Collins, J.K. Quality control Lactobacillus isolates for use with the API50 CH and API ZYM systems at $37^{\circ}$ C. J. Basic Microbiol. 2001, 41, 241-251.

[19] Klein, G. International Committee of Systematic Bacteriology, subcommittee on the taxonomy of bifidobacterium, lactobacillus and related organisms. Minutes of the meeting. Int. J. Syst. Evol. Microbiol. 2001, 51, 259-1.

[20] Harrigan, W.F and McCance, M.E. Laboratory Methods in Food and Dairy Microbiology, second ed. 1976, Academic Press, London.
[21] Schillinger, $U$ and Lucke, F.K. Antibacterial activity of Lactobacillus sakei isolated from meat. Applied and Environmental Microbiology, 1989, 55: 1901-1906.

[22] Ogunshe, A.A.O., Omotoso, M.A and Adeyeye, A. In vitro antimicrobial characteristics of bacteriocin - producing Lactobacillus strains from Nigerian indigenous fermented foods. African Journal of Biotechnology. 2007, 2(8): 219-227.

[23] Sarika, A.R., Lipton, A.P and Aishwarya, M.S. Bacteriocin production by new isolate of Lactobacillus rhamnosus GP1 under different culture conditions. Advance Journal of food Science and Technology. 2010, 25(5): 291-297.

[24] Aly, S., Cheik, A.T., Ouattara, I., Bassole, H.N and Alfred, S.T. Antimicrobial activities of lactic acid bacteria strains isolated from Burkina Faso fermented milk. Pakistan Journal of Nutrition. 2004, 3(3): 174-179.

[25] Sourav, B and Arijit, D. Study of Physical and cultural Parameters on the bacteriocins produced by lactic acid bacteria Isolated from Traditional Indian fermented Foods. American Journal of Food Technology. 2010, 5(2): 111-120.

[26] Karaoglu, A.S., Faruk, A., Kilic, S.S and Kilic, A.O. Antimicrobial activity and characteristics of bacteriocins produced by vaginal lactobacilli. Turkish Journal of Medical Sciences. 2003, 33: 7-13.

[27] Divakara, R., Manjunatha, B.K and kusum, P. Lactic acid bacteria as probiotics: Role in human health. Research Reviews in Biomedicine and Biotechnology. 2010, 1(1): 1-5.

[28] Zhao, C., Beilei, G., Vilena, J., Sudler, R., Yeh, E., Zhao, S., White, D.G., Wagner, D and Meng, A. Prevalence of Campylobacter spp., Escherichia coli and Salmonella serovars in retail chicken, turkey, pork and beef from the greater Washington DC area. Applied and Environmental Microbiology. 2000, 66: 5431-5436.

[29] Onwuakor, C.E and Ukaegbu-Obi, K.M. Synergistic Biopreservative Effects of Vernonia amygdalina Leaves and Sacoglottis gabonensis Stem Bark on Palm Wine from Elaeis guineensis and Raphia hookeri from Uturu, Nigeria.” American Journal of Microbiological Research. 2014, 2(3): 105-109

[30] Ogunshe, A.A.O., Ayodele, A.E and Okonko, O. Microbial studies on Aisa: A potential indigenous fermented food condiment from Albiziz saman (Jacq.). Pakistan Journal of Nutrition. 2005, 5(1): 51-58.

[31] Okereke, H.C, Achi, O.K, Ekwenye, U.N and Orji, F.A Antimicrobial properties of probiotic bacteria from various sources. African Journal of Biotechnology. 2012, 11(39): 94169421.

[32] Schnurer, J and Magnusson, J. Antifungal lactic acid bacteria as bio-preservatives. Trends in Food Science and Technology. 2005, 16: 70-78.

[33] Settanni, L and Corsetti, A. Application of bacteriocins in vegetable food bio-preservation. International Journal of Food Microbiology. 2008, 121: 123-138. 